\title{
Clinical Utility of Ultrasonographic Detection of Pleural Effusion for Evaluation of Heart Failure Patients
}

\author{
H. Kataoka \\ Nishida Hospital \\ Japan
}

\section{Introduction}

Because heart failure is a clinical syndrome that is caused by abnormal cardiac function, the major goals in the evaluation of patients with heart failure are: 1) to identify the nature and severity of the cardiac abnormality; 2) to characterize the nature and severity of the patient's functional limitation; and 3) to assess the presence and severity of body fluid retention (Packer \& Cohn, 1999). An accurate objective measurement of the presence of body fluid retention is necessary in order to evaluate whether or not heart failure status deteriorates. The difficulty in clinically defining such patients, however, stems from the fact that no simpler or more objective sign of body fluid accumulation is currently available because there is no clear cutoff sign of fluid accumulation that can be used reliably to identify subjects with worsening or decompensated heart failure (Gheorghiade et al., 2010). In the recent years, technologies available for the assessment of body fluid status in heart failure patients are increasing in number, variety, and availability (Abraham et al., 2011; Blair et al., 2009; Kataoka, 2009a, 2009b; McDonald, 2010; Tang \& Tong, 2009). Chest ultrasound to evaluate pleural effusion or changes in lung status is an evolving imaging technique with novel uses in critically ill patients, including those with heart failure (Bouhemad et al., 2007; Evans \& Gleeson, 2004; Havelock et al., 2010; Stefanidis et al., 2011). In uncontrolled heart failure, fluid accumulates throughout the body, including in the thorax. The accumulation and retention of body fluid in the pleural (Kataoka \& Takada, 2000; Kataoka, 2007, 2010) and/or pericardial (Kataoka, 2000; Movahed et al., 2006) cavities could be suitable targets for clinical evaluation by chest ultrasound in heart failure patients. This review article describes the application of this technique for the evaluation of pleural effusion in heart failure patients.

\section{Pathophysiology of heart failure-associated pleural effusion}

The pleural cavity contains a relatively small amount of fluid - approximately $10 \mathrm{ml}$ on each side (Sahn, 1988). Pleural fluid volume is maintained by a balance between fluid production and removal, and changes in the rates of either can potentially result in the presence of excess fluid, traditionally known as pleural effusion (Miserocchi, 1997; Natanzon \& Kronzon, 2009). Pathologic pleural effusion can be caused by a wide variety of intrathoracic and systemic diseases (Sahn, 1988). Pleural effusions are classified as either exudates, which 
indicate a structural pleural abnormality, or transudates, which indicate an imbalance of the hydrostatic and oncotic pressures across the normal pleura (Agostoni et al., 1957; Paddock, 1940). The main causes of structural pleural abnormalities include pulmonary infection, malignancy, pulmonary embolism, or collagen disease. Imbalanced pressure across the normal pleura, on the other hand, is due to heart failure, pulmonary atelectasis, hypoalbuminemia, hepatic hydrothorax, or nephritic syndrome (Azoulay, 2003; Golshan et al., 2002; Light et al., 1972; Mattison et al., 1997; Sahn, 1988). Decompensated heart failure with transudative pleural effusion is the most common cause of pleural effusion in many parts of the world.

The syndrome of heart failure is the response of the body to the heart's inability to maintain an adequate blood supply at a rate commensurate with the requirements of the metabolizing tissues. Arterial underfilling due to worsening of heart failure, either by diminished cardiac output or arterial vasodilatation, triggers activation of neurohormonal systems and derangement of renal function, that in turn incite heart failure-related body fluid retention (Ronco \& Maisel, 2010; Schrier \& Abraham, 1999; Sica, 2006), including pleural cavity. In decompensated heart failure, the accumulation of pleural effusion is more closely associated with left atrial pressure than right atrial pressure, suggesting that highpressure pulmonary edema due to left-sided heart failure, accumulating fluid in the lung passes through the visceral pleura and enters the pleural space (Wiener-Kronish et al., 1985, 1987). In this condition, an elevated right atrial pressure might help to sustain or worsen pleural effusion by interfering with lymphatic drainage from the lung (Szabo \& Magyar, 1967). The volume of pleural effusion, however, is not known to be associated with pericardial effusion in decompensated heart failure patients (Kataoka, 2000).

Early studies reported a right-sided predominance of heart-failure associated pleural effusion (Bedford \& Lovibond, 1941; McPeak \& Levine, 1946; White et al., 1947), but subsequent studies report mixed results regarding the lateralization of pleural effusion in heart failure, presumably due to differences in the assessment methods (Kataoka, 2000). A recent review article (Wong et al., 2009) systematically examined a large number of heart failure-associated pleural effusion studies and concluded: (1) most of the studies reported bilateral effusion, and (2) when asymmetry occurred, effusion was predominantly rightsided (either unilateral or one side larger than the other) with summary prevalence for unilateral or larger right-sided effusion at $47 \%$ compared with left-sided prevalence of $19 \%$. The findings of a previous study, in which heart failure-associated pleural effusion was quantitatively assessed using computed tomography, support the observations summarized above (Kataoka, 2000). In that study, as many as 52 (87\%) of 60 acutely decompensated heart failure patients had pleural effusion. Of 52 heart failure patients with pleural effusion, 45 $(87 \%)$ had bilateral effusion, $5(10 \%)$ had right-sided effusion only, and $2(3 \%)$ had left-sided effusion only. Among the 45 patients with bilateral pleural effusion, 20 (44\%) patients had predominantly right-sided effusion (interhemithoracic difference of the pleural volume $>$ $100 \mathrm{ml}), 23$ (51\%) patients had equally bilateral effusion, and only $2(5 \%)$ had predominantly left-sided effusion.

Multiple explanations for the asymmetry in heart failure-associated pleural effusion have been proposed based on the results of several studies. Among these studies of the right-side preponderance of pleural effusion in heart failure patients, one study presented impressive evidence that the anatomic and hydrostatic factors relating to blood flow from the 
pulmonary venous bed to the left ventricle strongly favored the predominance of pleural effusion in the right hemithorax (Dock, 1935). In addition, these factors are augmented by the generally preferred right lateral decubitus position of heart failure patients as revealed by studies on trepopnea (Wood, et al., 1937; de Araujo et al., 2011). An older study attributed the right side predominance of pleural effusion to the greater extent of lung and pleural surfaces on the right side relative to the left side (White et al., 1947). To date, however, none of the theories regarding the right-sided polarity of pleural effusion in patients with heart failure has been universally accepted (Natanzon \& Kronzon, 2009).

\section{Sonographic evaluation of pleural effusion in heart failure}

The classical symptoms of heart failure are dyspnea, palpitation, and fatigue. Dyspnea on exertion is common in the general population, particularly in patients with respiratory disease or in the obese, and, therefore, it cannot be used as the selection criterion for the diagnosis of heart failure. Orthopnea and paroxysmal nocturnal dyspnea are less common in the general population than dyspnea alone, but less sensitive, for the diagnosis of heart failure (Ahmed et al., 2004; Fonseca et al., 2004; Mueller et al., 2005).

Body fluid retention in worsening heart failure is reflected in physical signs of congestion, such as fluid body weight gain, leg edema, jugular venous distension and pulmonary crackles. As for pleural effusion, some studies suggest the possibility of physical examination maneuver to detect pleural effusion as little as $50 \mathrm{ml}$ (Bernstein \& White, 1952; Guarino \& Guarino, 1994). However, none of these physical signs of fluid retention is particularly sensitive, though specificity varies among studies (Fonseca et al., 2004; Mueller et al., 2005; Rohde et al, 2004; Stevenson \& Perloff, 1989; Tresch, 1997). These limited roles of heart failure-associated physical findings and poor prediction of symptoms for identifying worsening heart failure status emphasize the need for additional diagnostic tools. Chest ultrasound might be one of these diagnostic tools, but this modality is not yet in widespread use. Evaluation of the clinical utility of this method for assessing heart failure patients is therefore important.

\subsection{Chest ultrasound technique}

The patient is placed in a sitting position on a bed or chair, and chest ultrasound is performed on each hemithorax using a transducer through the intercostal space, and scanning is performed along the paravertebral, scapular, and posterior axillary lines (Kataoka \& Takada, 2000; Kataoka, 2007; Piccoli et al., 2005; Waggoner et al., 1995). Using a high resolution $(3.5-5.0 \mathrm{MHz})$ transducer applied to the chest wall, the parietal pleura lining the bony thorax and the visceral pleura covering the lung are seen just beneath the chest wall as two thin and bright echogenic lines. Normally, the two pleural lines are smooth and less than $2 \mathrm{~mm}$ thick (Mathis, 1997). These higher frequency transducers, while providing superior spatial resolution, may be limited by insufficient penetration (Warakaulle \& Traill, 2004) and thus inadequate for obese patient. The pleural space can be identified by observing the normal motion of the lung during breathing. The liver and spleen, and occasionally the kidney, are used as guides to chest ultrasound searching for the pleural effusion. The air-filled lung surface totally reflects the ultrasound beam and produces a bright, echogenic line of sound reflection (Figure 1A). This characteristic pattern of bright echoes produced by a reverberation artifact is recognized as normal for the air-filled lung 
and indicates the absence of a pleural effusion, but there is an observation that pointed out an appearance of 2-mm-thick pleural fluid layer in healthy individuals (Kocijančič et al., 2005). The presence of a pleural effusion is diagnosed by the appearance of an anechoic space between the parietal pleura and the highly reflective visceral pleura-lung interface. The amount of pleural effusion visualized on an ultrasonogram can be assessed quantitatively (Remérand et al., 2010; Vignon et al., 2005) or semi-quantitatively (Kataoka, 2007; Tsai et al., 2008). The following categories are one example of the semi-quantification of pleural effusion (Kataoka, 2007): small if the echo-free space is within the costophrenic angle, moderate if the echo-free space extends over the costophrenic angle and causes near separation of basal lung from the diaphragm, and large if the space is bigger and separates the basal lung from the diaphragm (Figures 1- B, C, D).
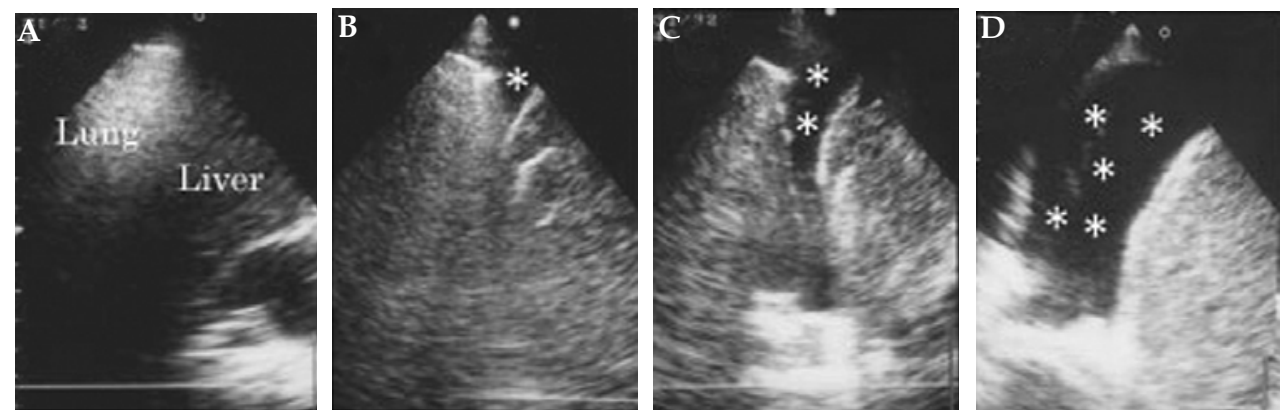

Fig. 1. Examples of pleural effusion. (A) absent, (B) small, (C) moderate, (D) large collection of fluid. Asterisks indicate pleural effusion. Adapted from Kataoka (2007). (Adapted and reproduced with permission from Wiley Periodicals, Inc.)

\subsection{Accuracy of sonographic detection of pleural effusion}

Radiographic identification of pleural effusion is reported to be insensitive and detects only moderate to large accumulation of pleural fluid. Pleural effusion becomes visible on the upright lateral radiograph at a volume of approximately $50 \mathrm{ml}$ as a meniscus in the posterior costophrenic sulcus. The meniscus becomes visible on the postero-anterior projection at a volume about 175 to $525 \mathrm{ml}$ (Woodring, 1984) or $200 \mathrm{ml}$ (Blackmore et al., 1996). To determine the accuracy of chest ultrasound for detecting pleural effusion in acutely decompensated heart failure patients, previous study evaluated the usefulness of chest ultrasound in comparison with physical signs, erect postero-anterior chest $\mathrm{x}$-ray, and thoracic x-ray computed tomography (Kataoka \& Takada, 2000). The incidence of pleural effusion detected by chest ultrasound was high when compared to plain chest radiograph (Table 1): postero-anterior projection of chest $x$-ray could not identify a very small amount (less than $100 \mathrm{ml}$ ) of pleural effusion, but chest ultrasound detected most of the pleural effusion. Many other studies have also confirmed the superiority of chest ultrasound for detection of small pleural effusion compared to simple chest radiographic technique (Gryminski et al., 1976; Kohan et al., 1986; Lipscomb et al., 1981; Yu et al., 1992; Zanobetti et al., 2011). Thus, the diagnosis of pleural effusions in critically ill patients has been revolutionized with the advent of chest ultrasound allowing easy bedside quantification of pleural fluid and making thoracentesis a safe procedure (Pneumatikos \& Bouros, 2008). 


\begin{tabular}{|c|c|c|c|c|c|c|}
\hline \multirow[b]{2}{*}{ Pleural Effusion by CT } & \multicolumn{3}{|c|}{ Right Hemithorax } & \multicolumn{3}{|c|}{ Left Hemithorax } \\
\hline & $\mathbf{n}$ & X-ray & Ultrasound & $\mathbf{n}$ & X-ray & Ultrasound \\
\hline \multicolumn{7}{|l|}{ Normal controls $(\mathrm{n}=22)$} \\
\hline Absent & 22 & 0 & 0 & 22 & 0 & $1(5 \%)$ \\
\hline \multicolumn{7}{|l|}{ Patient group $(n=60)$} \\
\hline Absent & 10 & 0 & $1(10 \%)$ & 14 & 0 & $2(14 \%)$ \\
\hline \multicolumn{7}{|l|}{ Present $(\mathrm{ml})$} \\
\hline Very small $(\leq 100)$ & 15 & $2(13 \%)$ & $13(87 \%)$ & 15 & 0 & $12(80 \%)$ \\
\hline Small $(\leq 400)$ & 20 & $9(45 \%)$ & $18(90 \%)$ & 23 & $6(26 \%)$ & $23(100 \%)$ \\
\hline Moderate $(\leq 700)$ & 8 & $6(75 \%)$ & $8(100 \%)$ & 6 & $4(67 \%)$ & $6(100 \%)$ \\
\hline Large & 7 & $7(100 \%)$ & $7(100 \%)$ & 2 & $2(100 \%)$ & $2(100 \%)$ \\
\hline Total & 50 & $24(48 \%)$ & $46(92 \%)$ & 46 & $12(26 \%)$ & $43(93 \%)$ \\
\hline
\end{tabular}

Table 1. Comparison of the presence of signs of pleural effusion between plain chest $x$-ray and chest ultrasound in normal controls and patients with decompensated chronic heart failure. Adapted from Kataoka \& Takada (2000). (Adapted and reproduced with permission from the American College of Cardiology)

\subsection{Clinical significance of ultrasound pleural effusion in heart failure patients}

In acutely worsening heart failure patients, the reported incidence of pleural effusion on chest ultrasound is high when compared to other heart failure-associated examinations (Kataoka \& Takada, 2000). Namely, an observation of 60 acutely decompensated heart failure patients indicated that the incidence of pulmonary rales or wheezing was modest $(56 \%)$ but that of other physical signs of jugular venous distension (38\%) and peripheral edema (33\%) was low. On erect postero-anterior plain chest radiograph, combined frequency of radiographic heart failure signs, consisting of the pulmonary edema $(45 \%)$ and/or pleural effusion (41\%), was low (61\%), but the presence of ultrasound pleural effusion was high (90\%). As such, diagnostic utility of chest ultrasound searching for pleural effusion in heart failure patients seems to be high in emergent situation.

Recent studies have reported that ultrasound signs of pleural effusion were a common presenting heart failure-related sign for established heart failure patients during follow-up (Kataoka, 2007; Kataoka, 2011), and were strongly associated with the appearance of other heart failure-related symptoms and signs (Kataoka, 2010). The results also demonstrated that the ultrasound signs of pleural effusion had high diagnostic value for identifying heart failure status worsening, confirming that this sign was a useful marker in such patients during follow-up (Kataoka, 2010). Importantly, ultrasound-detected pleural effusion signs were often present in asymptomatic heart failure worsening with the minimal appearance of other heart failure-related signs, which was supported by recent observation (Kataoka, 2011). Other than in the severity of leg edema, there were no differences in heart failurerelated signs between symptomatic $(n=45)$ and asymptomatic clinic visits $(n=38)$ with a positive ultrasound pleural effusion sign (Table 2). Unsuspected and not clinically apparent pleural effusion is easily detected by a simple chest ultrasound examination and may have an important bearing on therapeutic decisions and outcome. Detection of the ultrasound 
pleural effusion can potentially become one of the leading signs of deterioration in heart failure during follow-up of established heart failure patients. Thus, chest ultrasound should appropriately be performed in established heart failure patients, with or without symptomatic change, in order to obtain objective evidence of worsening heart failure status.

\begin{tabular}{|c|c|c|c|}
\hline \multirow{2}{*}{ Variables } & \multirow{2}{*}{$\frac{\text { Symptomatic Events }}{(\mathrm{n}=45)}$} & \multirow{2}{*}{$\begin{array}{c}\text { Asymptomatic Events } \\
(\mathrm{n}=38)\end{array}$} & \multirow{2}{*}{$P$ Value } \\
\hline & & & \\
\hline \multicolumn{4}{|c|}{ Amount of ultrasound pleural effusion } \\
\hline Small degree & $20(44 \%)$ & $24(63 \%)$ & \\
\hline Moderate degree & $18(40 \%)$ & $14(37 \%)$ & 0.0257 \\
\hline Large degree & $7(16 \%)$ & 0 & \\
\hline \multicolumn{4}{|l|}{ Heart failure-related signs } \\
\hline \multicolumn{4}{|l|}{ Leg edema } \\
\hline Mild & $12(27 \%)$ & $17(45 \%)$ & \\
\hline Moderate to severe & $19(42 \%)$ & 0 & \\
\hline Total & $31(69 \%)$ & $17(45 \%)$ & 0.044 \\
\hline Audible third heart sound & $11(24 \%)$ & $3(8 \%)$ & 0.075 \\
\hline Pulmonary rales & $12(27 \%)$ & $8(21 \%)$ & 0.613 \\
\hline Fluid body weight gain & $35(78 \%)$ & $23(61 \%)$ & 0.099 \\
\hline
\end{tabular}

Table 2. Comparison of heart failure-related signs between positive ultrasound pleural effusion events with $(n=45)$ and without $(n=38)$ symptomatic change. Values are presented as numbers (percentages)

In established heart failure patients during follow-up, effects of the volume of pleural effusion on heart failure-associated symptoms, signs, and the requirement of hospitalization are still unknown. Based on my clinical records of heart-failure monitoring in 83 established heart failure patients, I evaluated the pleural fluid volume dependency of symptoms and signs, and/or the requirement of hospitalization. The results of this analysis have shown that heart failure-related symptoms were not different, and only several signs were different between worsening heart failure events in patients with moderate to large pleural fluid retention and those in patients with small pleural effusion (Table 3). However, worsening heart failure events with moderate to large pleural fluid retention required more hospitalization than those with small pleural effusion. Thus, determining the volume of pleural effusion is clinically important because the amount of pleural effusion can affect the clinical course of individual heart failure patients.

\subsection{Differentiation of heart failure-associated pleural effusion from other causes}

Pleural effusion can be caused by a variety of intrathoracic and systemic diseases (Golshan et al., 2002; Mattison et al., 1997) which may necessitate thoracentesis to determine the cause of the effusion as described below in this section. In established heart failure patients, pleural effusion usually appears in relation to worsening heart failure during follow-up. Treatment with additional diuretics could resolve the pleural effusion in such cases, confirming the cause of effusion with high probability due to worsening heart failure. Persistent or increased amounts of pleural effusion despite added diuretic therapy during 
follow-up of established heart failure patients should first be considered a reflection of refractory heart failure and/or worsening of renal function, and requires concomitant consideration of other causes of pleural effusion. A review of my clinical records for heartfailure monitoring of 83 established heart failure patients (follow-up period of $652 \pm 456$ days) revealed unresolved pleural effusion due to refractory heart failure and/or renal failure in 12 study patients, but thoracentesis was required to reveal the cause in two other patients, one due to lung cancer and the other due to bacterial pneumonia (unpublished data).

Chest ultrasound provides information regarding the nature of pleural effusion, e.g., transudates are echo-free, whereas echoic effusions are likely to be exudates (Yang et al., 1992; Yu et al., 1992), but might be of limited value for identifying the cause of the pleural effusion. Thus, a persistent or increased amount of effusion on ultrasound despite the augmented treatment for decompensated heart failure status should be an indication for thoracentesis to evaluate the possible cause of effusions other than heart failure through analysis of the pleural fluid (Bartter et al., 1994; Light et al., 1972; Pneumatikos \& Bouros, 2008; Porcel et al., 2009; Porcel, 2011). In general, the traditional criteria of Light et al. (1972) (i.e., pleural fluid/serum total protein ratio $>0.5$, pleural fluid/serum LDH ratio $>0.6$, and pleural fluid LDH > 200 for identifying exudative pleural effusions) can be used to differentiate exudates from transudates with a negative predictive value of $96 \%$ and a sensitivity of $98 \%$. A high incidence of misclassifications by Light's criteria has been reported, however, in heart failure patients on diuretic therapy (Eid et al., 2002; Porcel et al., 2009; Romero-Candeira et al., 2001; Roth et al., 1990). In such heart failure patients, differences in the amount of albumin in the serum and pleural fluid (discriminating level; around $1.2 \mathrm{~g} / \mathrm{dl}$ ) are useful for differentiating exudates from transudates (Eid et al., 2002; Romero-Candeira et al., 2001; Roth et al., 1990).

\begin{tabular}{|c|c|c|c|}
\hline \multirow[b]{2}{*}{ Heart Failure-related Variable } & \multicolumn{2}{|c|}{ Volume of Pleural Effusion by Ultrasound } & \multirow[b]{2}{*}{$P$ Value } \\
\hline & $\begin{array}{l}\text { Small } \\
(\mathrm{n}=44)\end{array}$ & $\begin{array}{l}\text { Moderate to Large } \\
\qquad(\mathrm{n}=39)\end{array}$ & \\
\hline Heart failure-related symptoms & $20(45 \%)$ & $25(64 \%)$ & 0.123 \\
\hline \multicolumn{4}{|l|}{$\begin{array}{l}\text { Heart failure-related signs } \\
\text { Leg edema }\end{array}$} \\
\hline $\begin{array}{l}\text { Mild } \\
\text { Moderate to severe }\end{array}$ & $\begin{array}{c}15(34 \%) \\
9(20 \%)\end{array}$ & $\begin{array}{l}27(69 \%) \\
10(26 \%)\end{array}$ & 0.0001 \\
\hline Total & $24(55 \%)$ & $37(95 \%)$ & $\mathrm{P}<0.0001$ \\
\hline Audible third heart sound & $4(9 \%)$ & $10(26 \%)$ & 0.045 \\
\hline Pulmonary rales & $10(23 \%)$ & $10(26 \%)$ & 0.757 \\
\hline Fluid body weight gain & $27(61 \%)$ & $31(79 \%)$ & 0.073 \\
\hline Required hospitarization & $12(27 \%)$ & $20(51 \%)$ & 0.025 \\
\hline
\end{tabular}

Table 3. Pleural effusion volume dependency of symptoms and signs of heart failure. Values are presented as numbers (percentages) 
Recently, the pleural fluid level of natriuretic peptide, either B-type natriuretic peptide $(\mathrm{BNP})$ or the amono-terminal fragment $\mathrm{N}$-terminal pro-BNP (NT-pro-BNP), has been suggested as a useful adjunct for the diagnosis of heart failure-associated pleural effusion, including cardiac effusion misclassified as exudates by the criteria of Light (Kolditz et al., 2006; Liao, et al., 2008; Long et al., 2010; Porcel et al., 2004, 2009; Tomcsányi et al., 2004). Some studies have shown a strong correlation of natriuretic peptide concentrations in serum and pleural fluid and equal diagnostic accuracies for serum and pleural fluid natriuretic peptide measurements for the discrimination of pleural effusions attributable to heart failure (Kolditz et al., 2006; Tomcsányi et al., 2004). Therefore, it could be claimed that it may not be necessary to perform diagnostic thoracentesis in patients with serum natriuretic concentrations exceeding a cut-off value with a high positive predictive value, making the diagnosis of heart failure as the underlying cause of the pleural effusion very likely in these patients. However, in all other patients with serum natriuretic concentrations below such a cut-off value, early diagnostic thoracentesis may be necessary to determine whether the effusion is exudates or transudates in nature (Mueller \& Haltmayer, 2006).

\subsection{Advantages and limitations of thoracic sonography for evaluating heart failure}

This technique has several advantages for evaluating heart failure patients: 1) high diagnostic accuracy for diagnosing worsening heart failure through identifying ultrasound pleural effusion, e.g., bedside chest radiography is routinely performance under emergent conditions, but this technique offers limited diagnostic performance and efficacy for identifying pleural effusion (see sections " $3.2^{\text {" }}$ and " 4 "); 2 ) portability and performance ease at outpatient clinic or bedside with a hand-held device (Piccoli et al., 2005; Roelandt, 2003), e.g., though x-ray computed tomography has high diagnostic performance for identifying pleural effusion, this modality is not available or is not available quickly enough because it requires transportation of the patient to the radiology department; 3) short examination time, e.g., acquisition time to assess both hemithorax searching for pleural effusion is approximately 2 minutes (Tayal et at., 2006); 4) safety of the procedure due to the nonionizing nature of the examination; and 4) lower cost. Additionally, several studies have demonstrated that chest ultrasound can detect pulmonary edema (Agricola et al., 2005; Copetti et al., 2008; Jambrik et al., 2004; Lichtenstein et al., 1997, 2004; Zanobetti et al., 2011) and help to discriminate among the most important causes of acute dyspnea like pulmonary or cardiovascular diseases. The presence of diffuse "comet-tails" or B-line artifacts on chest ultrasound indicates diffuse alveolar-interstitial syndrome, which is often a sign of acute pulmonary edema. This condition rules out exacerbation of chronic obstructive pulmonary disease as the main cause of acute dyspnea (Lichtenstein \& Mezière, 1998; Volpicelli et al., 2008). These advantages make chest ultrasound a useful diagnostic tool with great potential for assisting decision-making and management of patients with heart failure. Several disadvantages include: 1) technical difficulty in obtaining a high quality of image in obese patients; 2) restricted field of view; and 3) somewhat operator-dependent findings.

\section{Reappraisal of chest $x$-ray for evaluation of heart failure patients}

Because chest radiography is still a standard method for evaluating fluid status in heart failure patients (Evans \& Gleeson, 2004; Logue et al., 1963; McHugh et al., 1972; Meszaros, 1973; Milne et al., 1985; Wiener et al., 1991), it is appropriate to briefly summarize the 
limitation of this modality for assessing heart failure status for comparison with the clinical role of chest ultrasound. Two important specific markers of fluid accumulation on plain chest radiograph are pleural effusion and interstitial edema (hilar haziness, peribronchial cuffing, Kerley's B lines, or septal lines) or alveolar pulmonary edema. An erect posteroanterior chest $\mathrm{x}$-ray should be performed wherever possible, including a lateral decubitus film, when necessary, for detecting small pleural effusions (Moskowitz et al., 1973). Though chest $x$-ray signs of interstitial/alveolar pulmonary edema and pleural effusion are important markers of fluid retention, the diagnostic accuracy of these $x$-ray signs of pulmonary congestion in chronic heart failure is not very high (Chakko et al., 1991; Collins et al., 2006; Gadsbøll et al., 1989; Mahdyoon et al., 1989), presumably due to increased lymphatic drainage clearing of the flooded interstitium/alveoli (Szidon et al., 1972). Also, as described above (see section "3.2"), chest x-ray identification of pleural effusion is not sensitive and only detects moderate to large amounts of accumulation. Thus, clinicians cannot rule out body fluid retention in heart failure patients without radiographic signs of pulmonary congestion, particularly in those without chest x-ray signs of pleural effusion. Chest ultrasound allows accurate evaluation of fluid accumulation in the thorax, including pleural effusion, and pulmonary congestion due to worsening heart failure (Agricola et al., 2005; Jambrik et al., 2004; Lichtenstein, et al., 1997, 2004; Zanobetti et al., 2011).

\section{Case presentation}

\subsection{Patient no.1}

A 75-year-old female patient visited the hospital emergently with a complaint of New York Heart Association functional class III dyspnea and night cough. Physical examination disclosed an audible third heart sound and mild ankle edema. Electrocardiographic findings included sinus tachycardia of 105 beats/minute and non-specific ST-T changes. Echocardiography revealed dilated, generalized hypokinesis of the left ventricle with an ejection fraction of $23 \%$ and a diastolic volume of $200 \mathrm{ml}$. An erect postero-anterior chest $x$-ray film showed moderate cardiomegaly with mild hypervascularity in the upper lung field, but no apparent pleural effusion (Figure 2). Chest ultrasound revealed the collection of a large pleural effusion in both hemithoraces. Computed tomography confirmed the chest ultrasound findings. Worsening of heart failure status due to dilated cardiomyopathy was confirmed by the marked elevation of serum B-type natriuretic peptide level of $1865 \mathrm{pg} / \mathrm{ml}$. The selected therapeutic option using extra-diuretics improved her clinical status; she lost $2.6 \mathrm{~kg}$ body weight and chest ultrasound confirmed complete resolution of the pleural effusion.

\subsection{Patient no.2}

During follow-up of a 78-year-old male patient with a history of decompensated heart failure due to hypertension, he experienced New York Heart Association functional class III dyspnea at a regular clinic visit, and underwent a scheduled examination. Physical examination revealed mild leg edema and diffuse basal rales on auscultation. The electrocardiogram showed a regular sinus rhythm of 72 beats/minute and left ventricular hypertrophy. On echocardiogram, left ventricular size and function were normal based on a left ventricular diastolic volume of $68 \mathrm{ml}$, ejection fraction of $65 \%$, and Doppler index of the ratio of mitral $\mathrm{E}$ wave to the $\mathrm{A}$ wave of 0.8 . Plain erect postero-anterior chest $\mathrm{x}$-ray was 

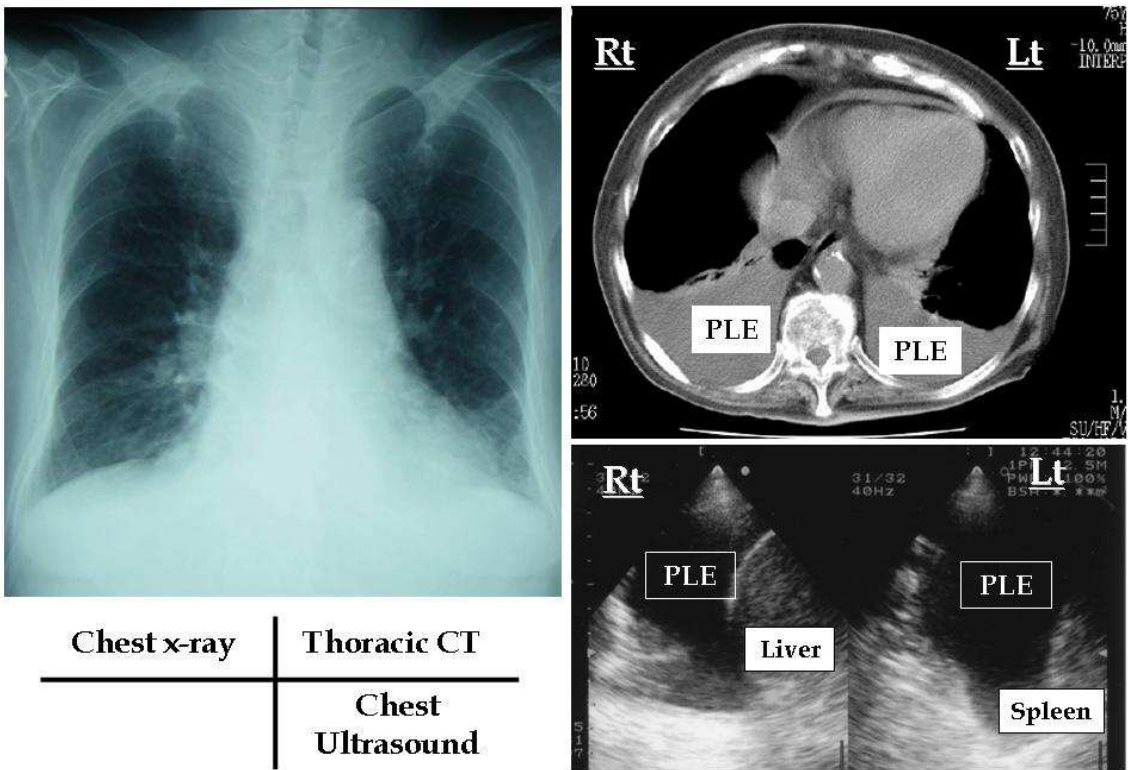

Fig. 2. Chest $x$-ray film, $x$-ray computed tomogram, and chest ultrasound obtained from a 75-year-old female with worsening heart failure due to idiopathic dilated cardiomyopathy. $\mathrm{Lt}=$ left; PLE = pleural effusion; Rt = right
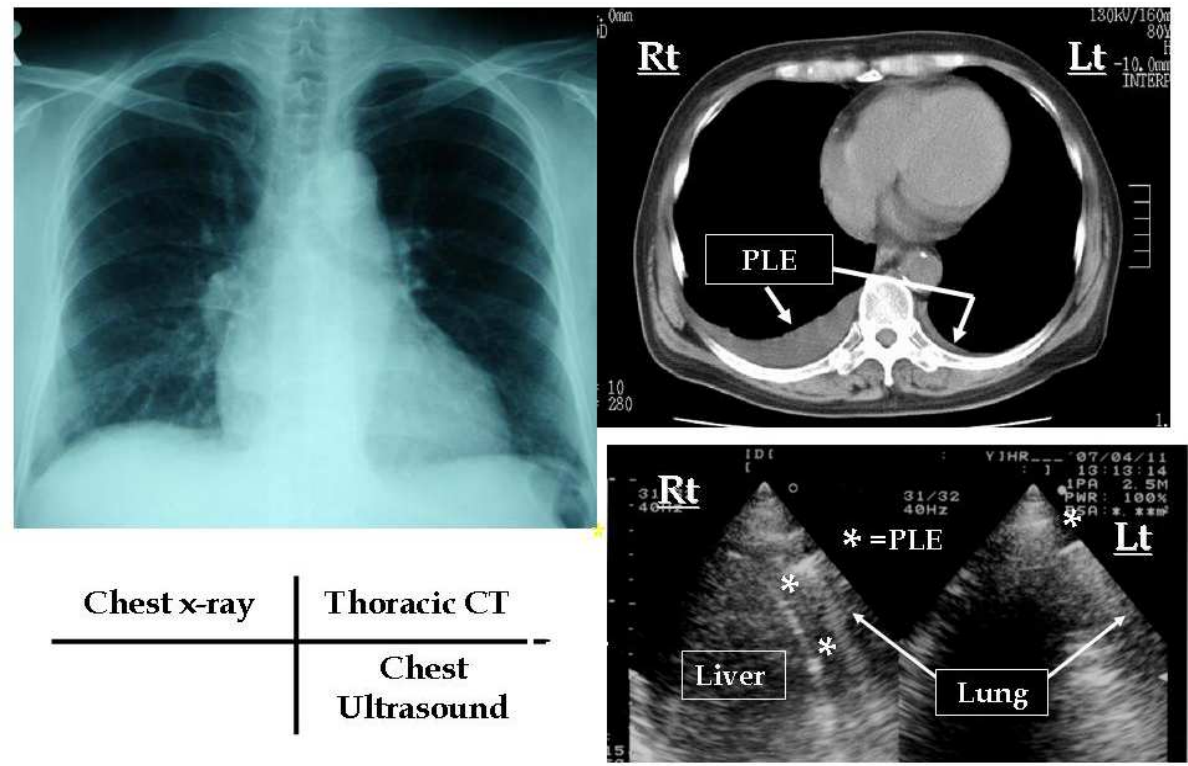

Fig. 3. Chest $x$-ray film, $x$-ray computed tomogram, and chest ultrasound obtained from a 78-year-old male with worsening heart failure due to hypertensive heart disease. Lt = left; PLE = pleural effusion; Rt $=$ right 
normal except moderate cardiomegaly (Figure 3). There was no evidence of pleural effusion on postero-anterior chest x-ray. Chest ultrasound disclosed a moderate amount of pleural effusion in the right hemithorax and a small collection in the left. Computed tomography confirmed the chest ultrasound findings. Serum B-type natriuretic peptide was increased to $381 \mathrm{pg} / \mathrm{ml}$ from $65 \mathrm{pg} / \mathrm{ml}$ measured at a recent clinic visit for clinical stability. Use of extradiuretics improved his clinical status with improvement of symptoms and lost of body weight of $3.1 \mathrm{~kg}$, and the pleural effusion disappeared on chest ultrasound.

\section{Conclusion}

Heart failure is a leading cause of hospitalization, particularly in the elderly population, and the frequency of heart failure-related hospital re-admission in heart failure patients within the first 3 to 6 months is high (Vinson et al., 1990; Krumholz et al., 1997; Fonarow et al., 2008). Heart failure-related hospitalizations are not benign events, with an increased (and independent) risk of mortality following the initial and each subsequent hospitalization for heart failure (Setoguchi et al., 2007; Solomon et al., 2007). Body fluid retention or congestion is the main characteristic feature for worsening heart failure, leading to hospitalization (Gheorghiade et al., 2006; Pang \& Levy, 2010). Thus, early detection of excess body fluid accumulation is crucial for identifying worsening heart failure events in patients with heart failure. As described in this chapter, the use of chest ultrasound to determine pleural effusion allows for sensitive detection of worsening heart failure and will improve diagnosis and facilitate decision-making in heart failure patients. Widespread use of ultrasound, a method that is not technically difficult to perform or analyze, to evaluate pleural effusion in patients with heart failure is therefore warranted, irrespective of the accompanying symptoms, and will lead to a more accurate diagnosis. Of course, it should be kept in mind that, a lot of patients without pleural effusion on chest ultrasound have deterioration of heart failure status. Fortunately, physicians rarely use single observation in clinical decisionmaking. Proper diagnosis of worsening heart failure requires clinicians to integrate elements of patient history, physical examination, and diagnostic test results together with knowledge of multiple pharmacologic and non-pharmacologic treatments.

\section{Future research}

Up to date, there is a paucity of data on the feasibility of using ultrasound pleural effusion as part of the diagnostic approach in patients with heart failure. Thus, additional study is necessary to answer the question of whether chest ultrasound pleural effusion may emerge as clinically useful in identifying worsening heart failure status.

\section{References}

[1] Abraham, WT., Adamson, PB., Bourge, RC., Aaron, MF., Costanzo, MR., Stevenson, LW., Strickland, W., Neelagaru, S., Raval, N., Krueger, S., Weiner, S., Shavelle, D., Jeffries, B. \& Yadav, JS., for the CHAMPION Trial Study Group. (2011). Wireless Pulmonary Artery Haemodynamic Monitoring in Chronic Heart Failure: A Randomised Controlled Trial. Lancet, Vol.377, No.9766, pp.658-666

[2] Agostoni, E., Taglietti, A. \& Setnikar, I. (1957). Absorption Force of the Capillaries of the Visceral Pleura in Determination of the Intrapleural Pressure. American Journal of Physiology, Vol.191, No.2, pp. 277-282 
[3] Agricola, E., Bove, T., Oppizzi, M., Marino, G., Zangrillo, A., Margonato, A. \& Picano, E. (2005). "Ultrasound Comet-Tail Images": A Marker of Pulmonary Edema - A Comparative Study with Wedge Pressure and Extravascular Lung Water. Chest, Vol.127, No.5, pp. 1690-1695

[4] Ahmed, A., Allman, RM., Aronow, WS. \& DeLong, JF. (2004). Diagnosis of Heart Failure in Older Adults: Predictive Value of Dyspnea at Rest. Archives of Gerontology and Geriatrics, Vol.38, No.3, pp. 297-307

[5] Azoulay, E. (2003). Pleural Effusions in the Intensive Care Unit. Current Opinion in Pulmonary Medicine, Vol.9, No.4, pp. 291-297

[6] Bartter, T., Santarelli, R., Akers, SM. \& Pratter, MR. (1994). The Evaluation of Pleural Effusion. Chest, Vol.106, No.4, pp. 1209-1214

[7] Bedford, DE. \& Lovibond, JL. (1941). Hydrothorax in Heart Failure. British Heart Journal, Vol.3, No.2, pp. 93-111

[8] Bernstein, A. \& White, FZ. (1952). Unusual Physical Findings in Pleural Effusion: Intrathoracic Manometric Studies. Annals of Internal Medicine, Vol.37, Vol.4, pp. 733738

[9] Blackmore, CC., Black, WC., Dallas, RV. \& Crow, HC. (1996). Pleural Fluid Volume Estimation: A Chest Radiograph Prediction Rule. Academic Radiology, Vol.3, No.2, pp. 103-109

[10] Blair, JE., Brennan, M., Goonewardena, SN., Shah, D., Vasaiwala, S. \& Spencer, KT. (2009). Usefulness of Hand-Carried Ultrasound to Predict Elevated Left Ventricular Filling Pressure. American Journal of Cardiology, Vol.103, No.2, pp. 246-247

[11] Bouhemad, B., Zhang, M., Lu, Q. \& Rouby, JJ. (2007). Clinical Review: Bedside Lung Ultrasound in Critical Care Practice. Critical Care, Vol.11, 205 (doi:10.1186/cc5668)

[12] Chakko, S., Woska, D., Martinez, H., de Marchena, E., Futterman, L., Kessler, KM. \& Myerburg, RJ. (1991). Clinical, Radiographic, and Hemodynamic Correlations in Chronic Congestive Heart Failure: Conflicting Results May Lead to Inappropriate Care. American Journal of Medicine, Vol.90, No.3, pp. 353-359

[13] Collins, SP., Lindsell, CJ., Storrow, AB., Abraham, WT., on behalf of the ADHERE Scientific Advisory Committee, Investigators and Study Group. (2006). Prevalence of Negative Chest Radiography Results in the Emergency Department Patient with Decompensated Heart Failure. Annals of Emergency Medicine, Vol.47, No.1, pp. 13-18

[14] Copetti, R., Soldati, G. \& Copetti, P. (2008). Chest Sonography: A Useful Tool to Differentiate Acute Cardiogenic Pulmonary Edema from Acute Respiratory Distress Syndrome. Cardiovascular Ultrasound, Vol.6: 16 (doi:10.1186/1476-7120-616)

[15] de Araujo, BS., Reichert, R., Eifer, DA., Soder, SA., dos Santos, MBS., Clausell, N. \& Beck-da-Silva, L. (2011). Trepopnea May Explain Right-Sided Pleural Effusion in Patients with Decompensated Heart Failure. American Journal of Emergency Medicine, doi:10.1016/j.ajem.2011.04.013

[16] Dock, W. (1935). The Anatomical and Hydrostatic Basis of Orthopnea and of Right Hydrothorax in Cardiac Failure. American Heart Journal, Vol.10, No.8, pp. 1047-1055

[17] Eid, AA., Keddissi, JI., Samaha, M., Tawk, MM., Kimmell, K. \& Kinasewitz, GT. (2002). Exudative Effusions in Congestive Heart Failure. Chest, Vol.122, No.5, pp. 15181523

[18] Evans, AL. \& Gleeson, FV. (2004). Radiology in Pleural Disease: State of the Art. Respirology, Vol.9, No.3, pp. 300-312 
[19] Fonarow, GC., Abraham, WT., Albert, NM., Stough, WG., Gheorghiade, M., Greenberg, BH., O'Connor, CM., Pieper, K., Sun, JL., Yancy, CW. \& Young, JB., for the OPTIMIZE-HF Investigators and Hospitals. (2008). Factors Identified as Precipitating Hospital Admissions for Heart Failure and Clinical Outcomes: Findings from OPTIMIZE-HF. Archives of Internal Medicine, Vol.168, No.8, 847-854

[20] Fonseca, C., Morais, H., Mota, T., Matias, F., Costa, C., Gouveia-Oliveira, A. \& Ceia, F., on behalf of the EPICA Investigators. (2004). The Diagnosis of Heart Failure in Primary Care: Value of Symptoms and Signs. European Journal of Heart Failure, Vol.6, No.6, pp. 795-800

[21] Gadsbøll, N., Høilund-Carlsen, PF., Nielsen, GG., Berning, J., Brunn, NE., Stage, P., Hein, E., Marving, J., Løngborg-Jensn, H. \& Jensen, BH. (1989). Symptoms and Signs of Heart Failure in Patients with Myocardial Infarction: Reproducibility and Relationship to Chest X-ray, Radionuclide Ventriculography and Right Heart Catheterization. European Heart Journal, Vol.10, No.11, pp. 1017-1028

[22] Gheorghiade, M., Filippatos, G., De Luca, L. \& Burnett, J. (2006). Congestion in Acute Heart Failure Syndromes: An Essential Target of Evaluation and Treatment. American Journal of Medicine, Vol.119, No.12 (Supplement 1), pp. S3-S10

[23] Gheorghiade, M., Follath, F., Ponikowski, P., Barsuk, JH., Blair, JEA., Cleland, JG., Dickstein, K., Drazner, MH., Fonarow, GC., Jaarsma, T., Jondeau, G., Lopez Sendon, J., Mebazaa, A., Metra, M., Nieminen, M., Pang, PS., Seferovic, P., Stevenson, LW., van Veldhuisen, DJ., Zannad, F., Anker, SD., Rhodes, A., McMurray, JJV. \& Filippatos, G. (2010). Assessing and Grading Congestion in Acute Heart Failure: A Scientific Statement from the Acute Heart Failure Committee of the Heart Failure Association of the European Society of Cardiology and Endorsed by the European Society of Intensive Care Medicine. European Journal of Heart Failure, Vol.12, No.5, pp. 423-433

[24] Golshan, M., Faghihi, M., Ghanbarian, K. \& Ghanei, M. (2002). Common Causes of Pleural Effusion in Referral Hospital in Isfahan, Iran 1997-1998. Asian Cardiovascular E Thoracic Annals, Vol.10, No.1, pp. 43-46

[25] Gryminski, J., Krakówka, P. \& Lypacewicz, G. (1976). The Diagnosis of Pleural Effusion by Ultrasonic and Radiographic Techniques. Chest, Vol.70, No.1, pp. 33-37

[26] Guarino, JR. \& Guarino, JC. (1994). Auscultatory Percussion: A Simple Method to Detect Pleural Effusion. Journal of General Internal Medicine, Vol.9, No.2, pp. 71-74

[27] Havelock, T., Teoh, R., Laws, D., Gleeson, F., on behalf of the BTS Pleural Disease Guideline Group. (2010). Pleural Procedures and Thoracic Ultrasound: British Thoracic Society Pleural Disease Guideline 2010. Thorax, Vol.65, Supplement 2, pp. ii61-ii76

[28] Jambrik, Z., Monti, S., Coppola, V., Agricola, E., Mottola, G., Miniati, M. \& Picano, E. (2004). Usefulness of Ultrasound Lung Comets as a Nonradiologic Sign of Extravascular Lung Water. American Journal of Cardiology, Vol.93, No.10, pp. 12651270

[29] Kataoka, H. \& Takada, S. (2000). The Role of Thoracic Ultrasonography for Evaluation of Patients with Decompensated Chronic Heart Failure. Journal of American College of Cardiology, Vol.35, No.6, pp. 1638-1646

[30] Kataoka, H. (2000). Pericardial and Pleural Effusions in Decompensated Chronic Heart Failure. American Heart Journal, Vol.139, No.5, pp. 918-923. 
[31] Kataoka, H. (2007). Utility of Thoracic Sonography for Follow-Up Examination of Chronic Heart Failure Patients with Previous Decompensation. Clinical Cardiology, Vol. 30, No.7, pp. 336-341

[32] Kataoka, H. (2009a). A New Monitoring Method for the Estimation of Body Fluid Status by Digital Weight Scale Incorporating Bioelectrical Impedance Analyzer in Definite Heart Failure Patients. Journal of Cardiac Failure, Vol.15, No.5, pp. 410-418

[33] Kataoka, H. (2009b). Novel Monitoring Method for the Management of Heart Failure: Combined Measurement of Body Weight and Bioimpedance Index of Body Fat Percentage. Future Cardiology, Vol.5, No.6, pp. 541-546

[34] Kataoka, H. (2010). UltraSound Pleural Effusion (US-PE) Sign as a Useful Marker for Identifying Worsening of Established Heart Failure Patients during Follow-Up. European Heart Journal, Vol.31, Supplement 1, pp. 278

[35] Kataoka, H. (2011). Detection of Preclinical Body Fluid Retention in Established Heart Failure Patients during Follow-Up by a Digital Weight Scale Incorporating a Bioelectrical Impedance Analyzer. Congestive Heart Failure, doi: 10.1111/j.17517133.2011.00230.x

[36] Kocijančič, K., Kocijančič, I. \& Vidmar, G. (2005). Sonography of Pleural Space in Healthy Individuals. Journal of Clinical Ultrasound, Vol.33, No.8, pp. 386-389

[37] Kohan, JM., Poe, RH., Israel, RH., Kennedy, JD., Benazzi, RB., Kallay, MC. \& Greenblatt, DW. (1986). Value of Chest Ultrasonography versus Decubitus Roentgenography for Thoracentesis. American Review of Respiratory Disease, Vol.133, No.6, pp. 11241126

[38] Kolditz, M., Halank, M., Schiemanck, CS., Schmeisser, A. \& Höffken, G. (2006). High Diagnostic Accuracy of NT-proBNP for Cardiac Origin of Pleural Effusions. European Respiratory Journal, Vol.28, No.1, pp. 144-150

[39] Krumholz, HM., Parent, EM., Tu, N., Vaccarino, V., Wang, Y., Radford, MJ. \& Hennen, J. (1997). Readmission after Hospitalization for Congestive Heart Failure among Medicare Beneficiaries. Archives of Internal Medicine, Vol.157, No.1, pp. 99-104

[40] Liao, H., NA, MJ., Dikensoy, O., Lane, KB., Randal, B. \& Light, RW. (2008). Diagnostic Value of Pleural Fluid N-Terminal Pro-Brain Natriuretic Peptide Levels in Patients with Cardiovascular Diseases. Respirology, Vol.13, No.1, pp. 53-57

[41] Lichtenstein D., Mézière, G., Biderman, P., Gepner, A. \& Barré, O. (1997). The CometTail Artifact: An Ultrasound Sign of Alveolar-Interstitial Syndrome. American Journal of Respiratory and Critical Care Medicine, Vol.156, No.5, pp. 1640-1646

[42] Lichtenstein, D. \& Mezière, G. (1998). A Lung Ultrasound Sign Allowing Bedside Distinction between Pulmonary Edema and COPD: The Comet-Tail Artifact. Intensive Care Medicine, Vol.24, No.12, pp. 1331-1334

[43] Lichtenstein, D., Goldstein, I., Mourgeon, E., Cluzel, P., Grenier, P. \& Rouby, JJ. (2004). Comparative Diagnostic Performances of Auscultation, Chest Radiography, and Lung Ultrasonography in Acute Respiratory Distress Syndrome. Anesthesiology, Vol.100, No.1, pp. 9-15

[44] Light, RW., MacGregor, I., Luchsinger, PC. \& Ball, WC. Jr. (1972). Pleural Effusions: The Diagnostic Separation of Transudates and Exudates. Annals of Internal Medicine, Vol.77, No.4, pp. 507-513

[45] Lipscomb, DJ., Flower, CDR. \& Hadfield, JW. (1981). Ultrasound of the Pleura: An Assessment of its Clinical Value. Clinical Radiology, Vol.32, No.3, pp. 289-290 
[46] Logue, RB., Rogers, JV. Jr. \& Gay, BB. Jr. (1963). Subtle Roentgenographic Signs of Left Heart Failure. American Heart Journal, Vol.65, No.4, pp. 464-473

[47] Long, AC., O'Neal, HR. Jr., Peng, S., Lane, KB. \& Light, RW. (2010). Comparison of Pleural Fluid N-Terminal Pro-Brain Natriuretic Peptide and Brain Natriuretic-32 Peptide Levels. Cheat, Vol.137, No.6, pp. 1369-1374

[48] Mahdyoon, H., Klein, R., Eyler, W., Lakier, JB., Chakko, SC. \& Gheorghiade, M. (1989). Radiographic Pulmonary Congestion in End-Stage Congestive Heart Failure. American Journal of Cardiology, Vol.63, No.9, pp. 625-627

[49] Mathis, G. (1997). Thoraxsonography - Part I: Chest Wall and Pleura. Ultrasound in Medicine E Biology, Vol.23, No.8, pp. 1131-1139

[50] Mattison, LE., Coppage, L., Alderman, DF., Herlong, JO. \& Sahn, SA. (1997). Pleural Effusions in the Medical ICU: Prevalence, Causes, and Clinical Implications. Chest, Vol.111, No.4, pp. 1018-1023

[51] McDonald, K. (2010). Monitoring Fluid Status at the Outpatient Level: The Need for More Precision. Congestive Heart Failure, Vol.16, Supplement 1, pp. S52-S55

[52] McHugh, TJ., Forrester, JS., Adler, L., Zion, D. \& Swan, HJC. (1972). Pulmonary Vascular Congestion in Acute Myocardial Infarction: Hemodynamic and Radiologic Correlations. Annals of Internal Medicine, Vol.76, No.1, pp. 29-33

[53] McPeak, EM. \& Levine, SA. (1946). The Preponderance of Right Hydrothorax in Congestive Heart Failure. Annals of Internal Medicine, Vol.25, No.6, pp. 916-927

[54] Meszaros, WT. (1973). Lung Changes in Left Heart Failure. Circulation, Vol.47, No.4, pp. 859-871

[55] Milne, ENC., Pistolesi, M., Miniati, M. \& Giuntini, C. (1985). The Radiologic Distinction of Cardiogenic and Noncardiogenic Edema. American Journal of Roentgenology, Vol.144, No.5, pp. 879-894

[56] Miserocchi, G. (1997). Physiology and Pathophysiology of Pleural Fluid Turnover. European Respiratory Journal, Vol.10, No.1, pp. 219-225

[57] Moskowitz, H., Platt, RT., Schachar, R. \& Mellins, H. (1973). Roentgen Visualization of Minute Pleural Effusion: An Experimental Study to Determine the Minimal Amount of Pleural Fluid Visible on a Radiograph. Radiology, Vol.109, No.1, pp. 3335

[58] Movahed, MR., Saito, Y., Ahmadi-Kashani, M. \& Kasravi, B. (2006). Relation of Pericardial Effusion to Degree of Fractional Shortening. American Journal of Cardiology, Vol.97, No.6, pp. 910-911

[59] Mueller, C., Frana, B., Rodriguez, D., Laule-Kilian, K. \& Perruchoud, AP. (2005). Emergency Diagnosis of Congestive Heart Failure: Impact of Signs and Symptoms. Canadian Journal of Cardiology, Vol.21, No.11, pp. 921-924

[60] Mueller, T. \& Haltmayer, M. (2006). Natriuretic Peptide Measurements as Part of the Diagnostic Work-Up in Pleural Effusions: An Emerging Concept? European Respiratory Journal, Vol.28, No.1, pp. 7-9

[61] Natanzon, A. \& Kronzon, I. (2009). Pericardial and Pleural Effusions in Congestive Heart Failure-Anatomical, Pathophysiologic, and Clinical Considerations. American Journal of Medical Sciences, Vol. 338, No.3, pp. 211-216

[62] Packer, MP. \& Cohn, JN. (1999). Consensus Recommendations for the Management of Chronic Heart Failure: Part I. Evaluation of Heart Failure. American Journal of Cardiology, Vol.83, No.2 (Supplement 1), pp. 2A-8A 
[63] Paddock, FK. (1940). The Diagnostic Significance of Serous Fluids in Disease. New England Journal of Medicine, Vol.223, No.25, pp. 1010-1015

[64] Pang, PS. \& Levy, P. (2010). Pathophysiology of Volume Overload in Acute Heart Failure Syndromes. Congestive Heart Failure, Vol.16, Supplement 1, pp. S1-S6

[65] Piccoli, M., Trambaiolo, P., Salustri,A., Cerquetani, E., Posteraro, A., Pastena, G., Amici, E., Papetti, F., Marincola, E., La Carruba, S. \& Gambelli, G. (2005). Bedside Diagnosis and Follow-Up of Patients with Pleural Effusion by a Hand-Carried Ultrasound Device Early after Cardiac Surgery. Chest, Vol.128, No.5, pp. 3413-3420

[66] Pneumatikos, I. \& Bouros, D. (2008). Pleural Effusions in Critically Ill Patients. Respiration, Vol.76, No.3, pp. 241-248

[67] Porcel, JM., Vives, M., Cao,G., Esquerda, A, Rubio, M. \& Rivas, C. (2004). Measurement of Pro-Brain Natriuretic Peptide in Pleural Fluid for the Diagnosis of Pleural Effusions due to Heart Failure. American Journal of Medicine, Vol.116, No.6, pp. 417420

[68] Porcel, JM., Martínez-Alonso, M., Cao, G., Bielsa, S., Sopena, A. \& Esquerda, A. (2009). Biomarkers of Heart Failure in Pleural Fluid. Chest, Vol.136, No.3, pp. 671-677

[69] Porcel, JM. (2011) Pearls and Myths in Pleural Fluid Analysis. Respirology, Vol.16, No.1, pp. $44-52$

[70] Remérand, F., Dellamonica, J., Mao, Z., Ferrari, F., Bouhemad, B., Jianxin, Y., Arbelot, C., Lu, Q., Ichaï, C. \& Rouby, JJ. (2010). Multiplane Ultrasound Approach to Quantify Pleural Effusion at the Bedside. Intensive Care Medicine, Vol.36, No.4, pp. 656-664

[71] Roelandt, JRTC. (2003). Ultrasound Stethoscopy: A Renaissance of the Physical Examination? Heart, Vol.89, No.9, pp. 971-974

[72] Rohde, LE., Beck-da-Silva, L., Goldraich, L., Grazziotin, TC., Palombini, DV., Polanczyk, CA. \& Clausell, N. (2004). Reliability and Prognostic Value of Traditional Signs and Symptoms in Outpatients with Congestive Heart Failure. Canadian Journal of Cardiology, Vol.20, No.7, pp. 697-702

[73] Romero-Candeira, S., Fernández, C., Martín, C., Sánchez-Paya, J. \& Hernández, L. (2001). Influence of Diuretics on the Concentration of Proteins and other Components of Pleural Transudates in Patients with Heart Failure. American Journal of Medicine, Vol.110, No.9, pp. 681-686

[74] Ronco, C. \& Maisel, A. (2010). Volume Overload and Cardiorenal Syndromes. Congestive Heart Failure, Vol.16, Supplement 1, pp. S1-S4

[75] Roth, BJ., O'Meara, TF. \& Cragun, WH. (1990). The Serum-Effusion Albumin Gradient in the Evaluation of Pleural Effusions. Chest, Vol.98, No.3, pp. 546-549

[76] Sahn, SA. (1988). State of the Art: The Pleura. American Review of Respiratory Disease, Vol.138, No.1, pp. 184-234

[77] Schrier, RW. \& Abraham, WT. (1999). Hormones and Hemodynamics in Heart Failure. New England Journal of Medicine, Vol.341, No.8, pp. 577-585

[78] Setoguchi, S., Stevenson, LW. \& Schneeweiss, S. (2007). Repeated Hospitalizations Predict Mortality in the Community Population with Heart Failure. American Heart Journal, Vol.154, No.2, pp 260-266

[79] Sica, DA. (2006). Sodium and Water Retention in Heart Failure and Diuretic Therapy: Basic Mechanisms. Cleveland Clinic Journal of Medicine, Vol.73, Supplement 2, pp. S2S7 
[80] Solomon, SD., Dobson, J., Pocock, S., Skali, H., McMurray, JJV., Granger, CB., Yusuf, S., Swedberg, K., Young, JB., Michelson, EL. \& Pfeffer, MA., for the Candesartan in Heart Failure: Assessment of Reduction in Mortality and morbidity (CHARM) Investigators. (2007). Influence of Nonfatal Hospitalization for Heart Failure on Subsequent Mortality in Patients with Chronic Heart Failure. Circulation, Vol.116, No.13, pp. 1482-1487

[81] Stefanidis, K., Dimopoulos, S. \& Nanas, S. (2011). Basic Principles and Current Applications of Lung Ultrasonography in the Intensive Care Unit. Respirology, Vol.16, No.2, pp. 249-256

[82] Stevenson, LW. \& Perloff, JK. (1989). The Limited Reliability of Physical Signs for Estimating Hemodynamics in Chronic Heart Failure. Journal of American Medical Association, Vol.261, No.6, pp. 884-888

[83] Szabo, G. \& Magyar, Z. (1967). Effect of Increased Systemic Venous Pressure on Lymph Pressure and Flow. American Journal of Physiology, Vol.212, No.6, pp. 1469-1474

[84] Szidon, JP., Pietra, GG. \& Fishman, AP. (1972). The Alveolar-Capillary Membrane and Pulmonary Edema. New England Journal of Medicine, Vol.286, No.22, pp. 1200-1204

[85] Tang, WHW. \& Tong, W. (2009). Measuring Impedance in Congestive Heart Failure: Current Options and Clinical Applications. American Heart Journal, Vol.157, No.3, pp. $402-411$

[86] Tayal, VS., Nicks, BA. \& Norton, HJ. (2006). Emergency Ultrasound Evaluation of Symptomatic Nontraumatic Pleural Effusions. American Journal of Emergency Medicine, Vol.24, No.7, pp. 782-786

[87] Tomcsányi, J., Nagy, E., Somlói, M., Moldvay, J., Bezzegh, A., Bózsik, B. \& Strausz, J. (2004). NT-Brain Natriuretic Peptide Levels in Pleural Fluid Distinguish between Pleural Transudates and Exudates. European Journal of Heart Failure, Vol.6, No.6, pp. 753-756

[88] Tresch, DD. (1997). The Clinical Diagnosis of Heart Failure in Older Patients. Journal of American Geriatric Society, Vol.45, No.9, pp. 1128-1133

[89] Tsai, T-H., Jerng, J-S. \& Yang, P-C. (2008). Clinical Applications of Transthoracic Ultrasound in Chest Medicine. Journal of Medical Ultrasound, Vol.16, No.1, pp. 7-25

[90] Vignon, P., Chastagner, C., Berkane, V., Chardac, E., François, B., Normand, S., Bonnivard, M., Clavel, M., Pichon, N., Preux, PM., Maubon, A. \& Gastinne, H. (2005). Quantitative Assessment of Pleural Effusion in Critically Ill Patients by Means of Ultrasonography. Critical Care Medicine, Vol.33, No.8, pp. 1757-1763

[91] Vinson, JM., Rich, MW., Sperry, JC., Shah, AS. \& McNamara, T. (1990). Early Readmission of Elderly Patients with Congestive Heart Failure. Journal of American Geriatrics Society, Vol.38, No.12, pp. 1290-1295

[92] Volpicelli, G., Cardinale, L., Garofalo, G. \& Veltri, A. (2008). Usefulness of Lung Ultrasound in the Bedside Distinction between Pulmonary Edema and Exacerbation of COPD. Emergency Radiology, Vol.15, No.3, pp. 145-151

[93] Waggoner, AD., Baumann, CM. \& Stark, PA. (1995). "Views from the Back" by Subscapular Retrocardiac Imaging: Technique and Clinical Application. Journal of American Society of Echocardiography, Vol.8, No.3, pp. 257-262

[94] Warakaulle, DR. \& Traill, ZC. (2004). Imaging of Pleural Disease. Imaging, Vol.16, No.1, pp. 10-21

[95] White, PD., August, S. \& Michie, CR. (1947). Hydrothorax in Congestive Heart Failure. American Journal of Medical Sciences, Vol.214, No.3, pp. 243-247 
[96] Wiener-Kronish, JP., Matthay, MA., Callen, PW., Filly, RA., Gamsu, G. \& Staub, NC. (1985). Relationship of Pleural Effusions to Pulmonary Hemodynamics in Patients with Congestive Heart Failure. American Review of Respiratory Disease, Vol.132, No.6, pp. 1253-1256

[97] Wiener-Kronish, JP., Goldstein, R., Matthay, RA., Biondi, JW., Broaddus, VC., Chatterjee, K. \& Matthay, MA. (1987). Lack of Association of Pleural Effusion with Chronic Pulmonary Arterial and Right Atrial Hypertension. Chest, Vol.92, No.6, pp. 967-970

[98] Wiener, MD., Garay, SM., Leitman, BS., Wiener, DN. \& Ravin, CE. (1991). Imaging of the Intensive Care Unit Patient. Clinics in Chest Medicine, Vol.12, No.1, pp. 169-198

[99] Wong, CL., Holroyd-Leduc, J. \& Straus, SE. (2009). Does this Patient have a Pleural Effusion? Journal of American Medical Association, Vol.301, No.3, pp. 309-317

[100] Wood, FC. Jr., Wolferth, CC. \& Terrell, AW. (1937). Trepopnea as an Etiological Factor in Paroxysmal Nocturnal Dyspnea. American Heart Journal, Vol.14, No.3, pp. 255267

[101] Woodring, JH. (1984). Recognition of Pleural Effusion on Supine Radiographs: How Much Fluid is Required? American Journal of Roentgenology, Vol.142, No.1, pp. 59-64

[102] Yang, P-C., Luh, K-T., Chang, D-B., Wu, H-D., Yu, C-J. \& Kuo, S-H. (1992). Value of Sonography in Determining the Nature of Pleural Effusion: Analysis of 320 Cases. American Journal of Roentgenology, Vol.159, No.1, pp. 29-33

[103] Yu, C-J., Yang, P-C., Chang, D-B. \& Luh, K-T. (1992). Diagnostic and Therapeutic Use of Chest Sonography: Value in Critically Ill Patients. American Journal of Roentgenology, Vol.159, No.4, pp. 695-701

[104] Zanobetti, M., Poggioni, C. \& Pini, R. (2011). Can Chest Ultrasonography Replace Standard Chest Radiography for Evaluation of Acute Dyspnea in the ED? Chest, Vol.139, No.5, pp. 1140-1147 


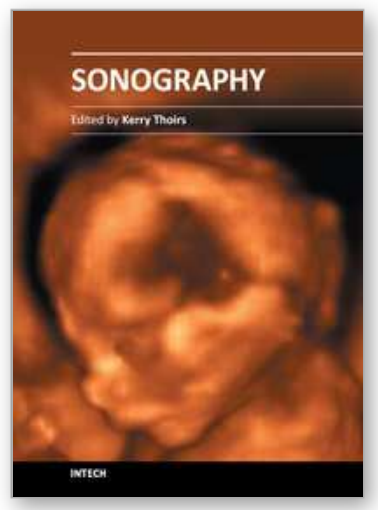

\author{
Sonography \\ Edited by Dr. Kerry Thoirs
}

ISBN 978-953-307-947-9

Hard cover, 346 pages

Publisher InTech

Published online 03, February, 2012

Published in print edition February, 2012

Medical sonography is a medical imaging modality used across many medical disciplines. Its use is growing, probably due to its relative low cost and easy accessibility. There are now many high quality ultrasound imaging systems available that are easily transportable, making it a diagnostic tool amenable for bedside and office scanning. This book includes applications of sonography that can be used across a number of medical disciplines including radiology, thoracic medicine, urology, rheumatology, obstetrics and fetal medicine and neurology. The book revisits established applications in medical sonography such as biliary, testicular and breast sonography and sonography in early pregnancy, and also outlines some interesting new and advanced applications of sonography.

\title{
How to reference
}

In order to correctly reference this scholarly work, feel free to copy and paste the following:

H. Kataoka (2012). Clinical Utility of Ultrasonographic Detection of Pleural Effusion for Evaluation of Heart Failure Patients, Sonography, Dr. Kerry Thoirs (Ed.), ISBN: 978-953-307-947-9, InTech, Available from: http://www.intechopen.com/books/sonography/clinical-utility-of-ultrasonographic-3detection-of-pleural-effusionfor-evaluation-of-heart-failure

\section{INTECH}

open science | open minds

\section{InTech Europe}

University Campus STeP Ri

Slavka Krautzeka 83/A

51000 Rijeka, Croatia

Phone: +385 (51) 770447

Fax: +385 (51) 686166

www.intechopen.com

\section{InTech China}

Unit 405, Office Block, Hotel Equatorial Shanghai

No.65, Yan An Road (West), Shanghai, 200040, China

中国上海市延安西路65号上海国际贵都大饭店办公楼405单元

Phone: +86-21-62489820

Fax: +86-21-62489821 
(C) 2012 The Author(s). Licensee IntechOpen. This is an open access article distributed under the terms of the Creative Commons Attribution 3.0 License, which permits unrestricted use, distribution, and reproduction in any medium, provided the original work is properly cited. 